\title{
Container Port Selection in West Africa: A Multi-Criteria Decision Analysis
}

\author{
Rivelino R. De Icaza ${ }^{1} \&$ Gregory Samuel Parnell ${ }^{1}$ \\ ${ }^{1}$ Department of Industrial Engineering, University of Arkansas, United States \\ Correspondence: Gregory Samuel Parnell, Department of Industrial Engineering, University of Arkansas, United \\ States. E-mail: gparnell@uark.edu
}

Received: March 5, 2018

doi:10.5539/emr.v7n1p68
Accepted: April 20, $2018 \quad$ Online Published: April 22, 2018

URL: http://doi.org/10.5539/emr.v7n1p68

\begin{abstract}
The West Africa gross domestic product is expected to grow and port expansion projects will increase capacity by over 12 million TEUs (Twenty-Foot Equivalent Units) by 2020. With the economic potential that the region offers and the steady growth of container traffic, the port selection decision by shipping lines is complex because the region has a poor shipping infrastructure and political instability that impact transportation security supply chain services. This research applies a multi-attribute value theory (MAVT) with value-focused thinking (VFT) and alternative-focused thinking (AFT) methodologies to develop a shipping lines' container port selection decision models for West Africa. Criteria and port alternatives from a previous published study were used in the research. The study demonstrates that a decision analysis model can be developed based on available quantitative port data rather than using data from surveys, interviews and questionnaires, as done in previous publications. In both approaches the Abidjan Port is the best option for shipping lines and the worst option is the Lagos Port. The VFT approach offers graphical displays that help decision makers understand strengths, weaknesses, tradeoffs, and improvement opportunities for each port alternative.
\end{abstract}

Keywords: port selection, multi-attribute value theory, value-focused thinking, multi-criteria decision analysis, decision analysis.

\section{Introduction}

Ports are considered an integral part of maritime industry and global supply chains. Over 90 percent of global trade is carried by sea (IMO, 2012). A port's performance can influence the global trade, the growth of the regional economy, and the competitiveness of the supply chain. Therefore, port selection is critical for shipping lines to offer competitive services and add value to the supply chain of their customers. With global supply chains, port selection is a complex and dynamic decision, involving the analysis of multiple and conflicting criteria including port capacity, infrastructure, safety, location, intermodal links, security, service level, costs, etc. (Guy \& Urli, 2006; Chou, 2010).

Therefore, port selection is an important strategic decision for shipping lines. Using multiple criteria decision analysis (MCDA) can be valuable for these complex decisions because it helps to structure and understand the problem with multiple and conflicting criteria (Belton \& Stewart, 2002) and involves different stakeholders with their own values and objectives (Montibeller, 2005). Although MCDA methods have been used to analyze the port selection problem (Dyck \& Ismael, 2015; Gohomene, Bonsal, Maistralis, Wang, \& Li, 2015; Yeo, Ng, Lee, \& Yang, 2014; Alanda \& Yang, 2013; Chou, 2010; Chou, 2007; Ugboma, Ugboma, \& Ogwude, 2006; Guy \& Urli, 2006; Song \& Yeo, 2004; Lirn, Thanopoulou, Beynon, \& Beresford, 2004; Frankel, 1992) the literature is silent regarding the application of the multi-attribute value theory (MAVT) approach.

The purpose of this study is to investigate the container port selection decision of the main ports in West Africa, applying a MAVT with Value-Focused Thinking (VFT) and Alternative-Focused Thinking (AFT) methodologies.

More specifically, the study aims to achieve the following specific research objectives:

- To use a qualitative decision hierarchy (objectives and criteria) and alternatives of a recently published study, Gohomene et al. (Gohomene, Bonsal, Maistralis, Wang, \& Li, 2015), in order to develop a MAVT model with a VFT methodology. 
- To demonstrate that MAVT with VFT methodology can be used as a new approach to the port selection decision problems, and develop a framework for obtaining the quantitative port data to use decision analysis.

- $\quad$ To compare AFT vs VFT, describing their advantages and disadvantages. AFT, first identifies the current available alternatives and then evaluates the alternatives, while the VFT approach first involves an understanding of the values and then identifies the alternatives for the decision problem (Keeney, 1992).

The study will demonstrate that port selection decision analysis can be developed based on available quantitative port data rather than using data from surveys, interviews and questionnaires. This research identifies available sources of quantitative port data, to score the port alternatives against each of the measures of the value hierarchy, input that is necessary to develop the multi-attribute value function (MAVF) approach with local and global scales (Belton \& Stewart, 2002). In addition, this study will use swing weights, which are based on the importance and scale variation of the criteria (Parnell \& Trainor, 2009).

The paper is structured as follows. In Section 2, the port selection literature is presented. In Section 3, the MAVT with VFT methodology of the container port selection in West Africa is developed, as well as the AFT approach. In Section 4, the results of the research are discussed. The article concludes in Section 5 with a summary of the study's contributions and directions for future research.

\section{Literature Review}

The port selection topic has been investigated (Frankel, 1992; Murphy, Dalenberg, \& Daley, 1988; Murphy, Daley, \& Dalenberg, 1991; Murphy, 1992; Slack, 1985) and is an active research area due to the changes in the maritime industry and the different stakeholders involved in the port selection process. A review of the port selection literature, presenting a structured summary of the studies by classifying the studies based on type of research analytics, year, criteria, methodologies, etc., are documented in (De Icaza, 2017).

In general, the port selection literature includes multiple and conflicting criteria, has two or more port alternatives, concentrates on a geographic region, and focuses on the perspective of a decision maker such as freight forwarders, shipping lines, shippers, and port management, etc. The criteria used in the port selection literature have been identified based on surveys, interviews, Delphi approach, previous research, etc. Due to the competitiveness and changes in the maritime industry: technology, location, shipping line alliances, vessel and port capacity, environment, costs, operations, logistics development, etc. researchers have not agreed on a list of criteria to analyze the port selection decision problem (Sanchez, $\mathrm{Ng}, \&$ Garcia-Alonso, 2011). As illustrated in Figue 1, the port selection literature demonstrates the use of multiple and conflicting criteria. 


\section{Location}

- Proximity of port to origin/ destination

- Accesslbillty of the port

- Dislance lo demand regions

- Dislance ol shipper Irom porl

- Geographical location

- Distance to niche market

- Proximity to hinterland

\section{Efficiency}

- Congestlon and shlp calls

- Speed getting throughport

- velays in loading/unloading containers

- TEU handled at port

- Ship turnaround time

- Annual operating hours

- Trade volume

- Lead time

\section{Administration}

- Port authority policy and regulation

- Professional personnel in port and services

- Reputation of port

- Relationships with shipping lines and workers

- Effort of marketing

- Carbon nculralily/ carbur Ioulprinl

Infrastructure
- Quay length
- \# of berths
- \# of cranes
- Water depth
- Capacily
- Fquipment availability
- Quality of container handling infrastructure

\section{Logistics/ Supply Chain}

- Connectlvity and flexlbility

- Inlermodal links availability

- Quality of customs handling

- I ogistics services

- Hinterland condition

- Quick response to user needs and reputation

- I.T. and advanced tech.

\section{Costs}

- Port charges

- Inland freight charges

- Transshipment costs

- Logistics costs

- Terminal handing costs

- Slorage cosls

- Marirne service cosls

- Cargo dues

Figure 1. Multiple and conflicting criteria in port selection research - source: (De Icaza, 2017).

* Bold criteria are related to criteria in Figure 3.

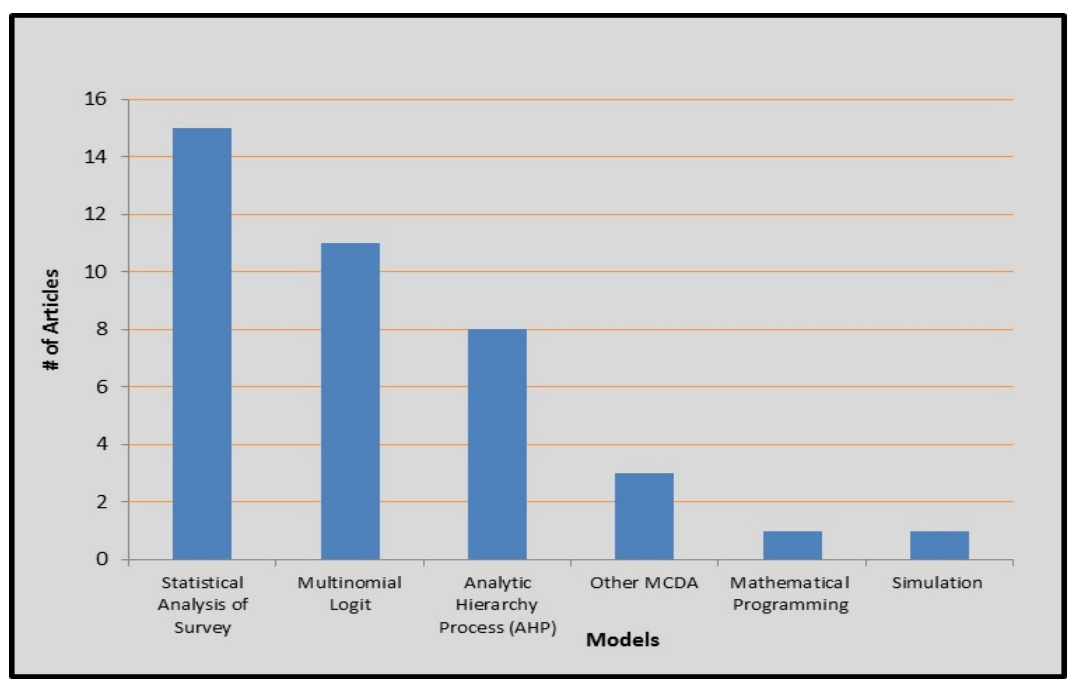

Figure 2. Models Applied to Port Selection Articles - Source: (De Icaza, 2017) 
In addition, different methodologies have been used to analyze the port selection problem, as illustrated in Figure . Most of the port selection research have used the Statistical Analysis of Survey methodology, using interviews or surveys data from stakeholders (Chang, Lee, \& Tongzon, 2008; De Langen, 2007; Grosso \& Monteiro, 2009; Kim, 2014; Mangan, Lalwani, \& Gardner, 2002; Murphy, 1992; Murphy \& Daley, 1994; Ng, 2006; Panayides \& Song, 2012; Sanchez, Ng, \& Garcia-Alonso, 2011; Slack, 1985;Tongzon, 2002; Tongzon, 2009; Tongzon \& Sawant, 2007; Wiegmans, Hoest, \& Notteboom, 2008).

Multinomial Logit Model has been another popular method applied in the port selection literature. Some of the studies used subjective data for the development of the methodology (Nir, Lin, \& Liang, 2003; Tiwari, Itoh, \& Doi, 2003; Wu, Liu, \& Peng, 2014); other studies concentrated on existing data to develop their model (Garcia-Alonso \& Sanchez-Soriano, 2009; Malchow \& Kanafani, 2001; Malchow \& Kanafani, 2004; Steven \& Corsi, 2012; Tang, Low, \& Lam, 2011; Veldman, Garcia-Alonso, \& Vallejo-Pinto, 2011; Veldman \& Bückmann, 2003); while (Magala \& Sammons, 2008) presented a new port selection modelling approach based on a conceptual framework.

The AHP developed by Saaty (1980) is a structured technique for dealing with complex decision-making problems and enables decision makers to represent the interaction of multiple factors in complex and unstructured situations. AHP has been used on several port selection problems (Alanda \& Yang, 2013; Chou, 2010; Frankel, 1992; Gohomene, Bonsal, Maistralis, Wang, \& Li, 2015; Lirn, Thanopoulou, Beynon, \& Beresford, 2004; Song \& Yeo, 2004; Ugboma, Ugboma, \& Ogwude, 2006; Dyck \& Ismael, 2015). The studies used input data based on pairwise comparison judgements of the decision criteria. Other MCDA methods that have been applied to the port selection research are the Fuzzy MCDM method (Chou, 2010; Yeo, Ng, Lee, \& Yang, 2014) and the outranking method PROMETHEE (Guy \& Urli, 2006).

The review of literature demonstrates that port selection is a multicriteria decision problem and there is a lack of research using MAVT; therefore, this research will demonstrate quantitative data exists to enable the development of a MAVT model for the port selection decision problem and illustrate the benefits of MAVT. Ralph Keeney (1992) described the two different decision making thinking styles: VFT and AFT approaches. The latter is the traditional and more common approach, which concentrates first on a current set of alternatives and then selects the best choice based on the values and preferences applied to them. This approach limits the decision maker creativity and new opportunities exploration (Wright \& Goodwin, 1999). In contrast, VFT focuses first on understanding and using the values and objectives, and later on the evaluation of alternatives (current set and an ideal alternative) to achieve these values (Keeney, 1992; Keeney, 1994). According to a VFT survey paper (Parnell et al., 2013), which included 89 journal articles in a period of 18 years, it was observed that VFT was used on $65 \%$ of the articles to evaluate alternatives and $32 \%$ of the articles to design or improve alternatives. This study will develop the MAVT with VFT for the container port selection decision in West Africa, to evaluate, rank, and improve the port alternatives.

\section{Research Methodology}

\subsection{MAVT With VFT for the Container Port Selection Decision Model}

MAVT with VFT methodology has been selected to develop a shipping lines' container port selection decision model in West Africa using the decision hierarchy (4 objectives and 16 criteria, Figure 3 ) and port alternatives of a recent published study (Gohomene, Bonsal, Maistralis, Wang, \& Li, 2015). The alternative-focused thinking (AFT) approach will also be developed in order to compare the results of both approaches for the container port selection decision problem. The axioms and conditions of the MAVT approach are defined by Keeney and Raiffa (1976). Belton and Stewart (2002) provides an in-depth explanation of the approach.

\subsubsection{Using a Decision Hierarchy from Literature}

The value hierarchy is fundamental to determine what is important for the decision problem and to provide the basis for the evaluation of the value model (Davis, Deckro, \& Jackson, 2000). The value hierarchy shown in Figure 3 was constructed using the decision hierarchy (set of 16 criteria clustered in 4 groups) of a recent published journal article (Gohomene, Bonsal, Maistralis, Wang, \& Li, 2015) using AHP. They identified important criteria for the West African container port selection decision by identifying 30 criteria from their literature review and interviews with experts. The criteria were reduced to 16 (Figure 3) using a survey conducted to a panel of four experts on container shipping in West Africa ( 3 senior managers and 1 senior lecturer from academia).

\subsubsection{Convert Decision Hierarchy to Value Hierarchy}

The first step of the VFT process was to develop a multi-attribute value model that provides a framework for the evaluation of the alternatives (Figure 3). The main purpose of the value model is described in level 1 of the value 
hierarchy. Then, it is divided in 4 general groups (level 2), and subsequently the set of criteria is presented in level 3 of the hierarchy. Finally, attributes (level 4) were identified for each of the 16 criteria.

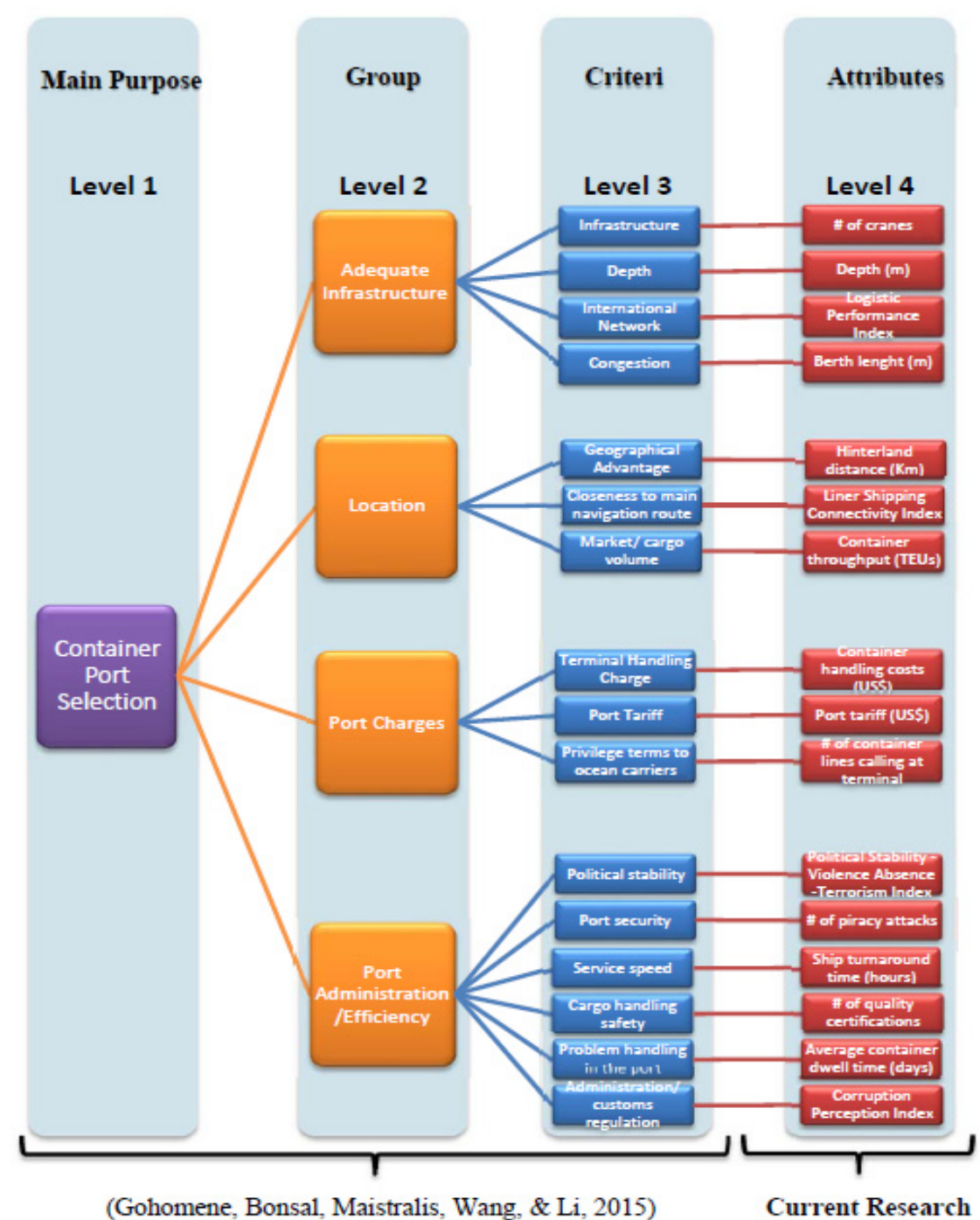

Figure 3. Value hierarchy for the container port selection value model

\subsubsection{Defining the Attributes}

For each criteria of the value model, an attribute was identified (Figure 3). Attributes serve as a measure of performance to evaluate how well an alternative performs with respect to the criteria on the value model (Belton \& Stewart, 2002; Keeney, 1992). In addition, two types of scales can be used for the attributes, natural and constructed. Natural scales are already well-known and commonly interpreted by people, while constructed value scales are developed for a specific decision problem (in which a natural scale does not exists) and use a set of qualitative levels to assess the criteria (Belton \& Stewart, 2002).

The goal of this research was to identify quantifiable attributes with natural scales and ready available data for each attribute of the value model. Through research, we identified data available on the internet (reports, documents, etc.) from different reliable sources to score alternatives against each of the attributes of the port selection value model (Table 1). It is one of the most critical steps of the research because it demonstrates that available data can be collected to evaluate a container port selection decision.

Using the collected research data shown in Table 1, extreme points of the scales for each attribute were defined and shown in Table 2. Extreme points of the scales are important to develop the scales and partial value functions of the model. Since VFT approach uses Global scale, it goes from the minimum acceptable level (column 3) to 
the ideal level (column 5) for each attribute. Data for the Ideal Port (Ideal Level) is related to one of the top ports in Africa, Port Said East located in Egypt, which is ranked among the top 50 world container ports (World Shipping Council, 2016).

Regarding the Best Level, column 4 on Table 2, it is an extreme point of the scale for the AFT approach, which is explained in section 3.2.1.

Table 1. Alternative scoring for each attribute

\begin{tabular}{|c|c|c|c|c|c|c|c|c|c|c|c|c|c|c|c|c|}
\hline Ports & $\begin{array}{c}\text { \# of } \\
\text { cranes }\end{array}$ & $\begin{array}{l}\text { Depth } \\
\text { (m) }\end{array}$ & $\begin{array}{l}\text { Logistics } \\
\text { Performan } \\
\text { ce Index } \\
(1-5)\end{array}$ & $\begin{array}{c}\text { Berth } \\
\text { length } \\
\text { (m) }\end{array}$ & $\begin{array}{c}\text { Hinterland } \\
\text { distance } \\
(\mathrm{Km})\end{array}$ & $\begin{array}{c}\text { Liner } \\
\text { Shipping } \\
\text { Connectivity } \\
\text { Index } \\
(0-100)\end{array}$ & $\begin{array}{c}\text { Container } \\
\text { throughput } \\
\text { (TEUs) }\end{array}$ & $\begin{array}{l}\text { Container } \\
\text { handling } \\
\text { costs } \\
\text { (US\$) }\end{array}$ & $\begin{array}{c}\text { Port tariff } \\
\text { (US\$) }\end{array}$ & $\begin{array}{c}\# \text { of } \\
\text { container } \\
\text { lines calling } \\
\text { at terminal }\end{array}$ & $\begin{array}{c}\text { Political } \\
\text { Stabilityl } \\
\text { Terrorism } \\
\text { Index } \\
(0-100)\end{array}$ & $\begin{array}{c}\text { \# of piracy } \\
\text { attacks }\end{array}$ & $\begin{array}{c}\text { Ship } \\
\text { turnaround } \\
\text { time } \\
\text { (hours) }\end{array}$ & $\begin{array}{l}\text { \# of quality } \\
\text { certifications }\end{array}$ & $\begin{array}{c}\text { Average } \\
\text { container } \\
\text { dwell time } \\
\text { (days) }\end{array}$ & $\begin{array}{c}\text { Corruption } \\
\text { Perception } \\
\text { Index } \\
(0-100)\end{array}$ \\
\hline $\begin{array}{l}\text { Abidjan } \\
\text { Port }\end{array}$ & 22 & 11.5 & 2.76 & 1,000 & 1238 & 21.9 & 783,102 & 260 & 12005 & 29 & 12.62 & 3 & 1 & 3 & 12 & 32 \\
\hline Dakar Port & 18 & 13 & 2.62 & 660 & 2075 & 12.9 & 450,008 & 160 & 12402 & 22 & 41.26 & 0 & 24 & 3 & 7 & 43 \\
\hline Lagos Port & 22 & 13.5 & 2.81 & 1,005 & 1376 & 22.9 & $1,062,389$ & 155 & 19963 & 16 & 5.34 & 18 & 12 & 1 & 42 & 27 \\
\hline Lome Port & 11 & 12 & 2.32 & 430 & 1272 & 19.1 & 223,465 & 220 & 3973 & 21 & 39.32 & 2 & 1 & 1 & 13 & 29 \\
\hline Tema Port & 16 & 11.5 & 2.63 & 574 & 1181 & 21.7 & 833,771 & 168 & 3442 & 25 & 40.78 & 4 & 32 & 1 & 25 & 48 \\
\hline $\begin{array}{l}\text { Ideal Port/ } \\
\text { Port Said } \\
\text { East }\end{array}$ & 76 & 16 & 5 & 1,200 & 1000 & 61.8 & $8,810,990$ & 151 & 3000 & 32 & 100 & 0 & 1 & 5 & 5 & 100 \\
\hline Source & $\begin{array}{r}\text { (Port Repo } \\
201\end{array}$ & t Africa, & $\begin{array}{c}\text { (World Bank } \\
\text { LPI, 2014) }\end{array}$ & \multicolumn{2}{|c|}{ (Dyck \& Ismael, 2015) } & $\begin{array}{l}\text { (World Bank } \\
\text { WDI, 2014) }\end{array}$ & $\begin{array}{c}\text { (UNCTAD } \\
\text { STAT, 2014) }\end{array}$ & $\begin{array}{c}\text { (Dyck \& } \\
\text { Ismael, } \\
\text { 2015) }\end{array}$ & $\begin{array}{c}\text { (CATRAM } \\
\text { Consultants } \\
, 2013 \text { ) }\end{array}$ & $\begin{array}{c}\text { (Port Report } \\
\text { Africa, 2014) }\end{array}$ & $\begin{array}{c}\text { (World Bank } \\
\text { WGI, 2014) }\end{array}$ & \begin{tabular}{|c|} 
(ICC \\
International \\
Maritime \\
Bureau ,2015) \\
\end{tabular} & $\begin{array}{c}\text { (Knoema - } \\
\text { Port Databse, } \\
\text { 2014) }\end{array}$ & $\begin{array}{c}\text { (Port of } \\
\text { Abidjan, Ivory } \\
\text { Coast, n.d.) }\end{array}$ & $\begin{array}{c}\text { (Dyck \& } \\
\text { Ismael, } \\
\text { 2015) }\end{array}$ & $\begin{array}{l}\text { (Transparency } \\
\text { International, } \\
\text { 2014) }\end{array}$ \\
\hline
\end{tabular}


Table 2. Attribute data to develop partial value functions

\begin{tabular}{|c|c|c|c|c|c|c|}
\hline $\begin{array}{l}\text { Criteria } \\
\text { (1) }\end{array}$ & $\begin{array}{l}\text { Attribute } \\
\text { (2) }\end{array}$ & $\begin{array}{c}\text { Min } \\
\text { Acceptable } \\
\text { Level } \\
\text { (3) }\end{array}$ & $\begin{array}{c}* \\
\text { Best } \\
\text { Level } \\
(4)\end{array}$ & $\begin{array}{c}* * \\
\text { Ideal } \\
\text { Level } \\
(5)\end{array}$ & $\begin{array}{l}\text { Curve } \\
\text { Shape } \\
\text { (6) }\end{array}$ & $\begin{array}{l}\text { Source } \\
(7)\end{array}$ \\
\hline Port Infrastructure & \# of cranes & 11 & 22 & 76 & Linear & $\begin{array}{c}\text { (Port Report Africa } \\
\text { 2014) }\end{array}$ \\
\hline Port depth & Depth (meters) & 11.5 & 13.5 & 16 & Convex & $\begin{array}{c}\text { (Port Report Africa } \\
\text { 2014) }\end{array}$ \\
\hline $\begin{array}{l}\text { Intermodal } \\
\text { network }\end{array}$ & $\begin{array}{l}\text { Logistic Performance } \\
\text { Index (1-5) }\end{array}$ & 2.32 & 2.81 & 5 & Linear & $\begin{array}{c}\text { (World Bank LPI, } \\
\text { 2014) }\end{array}$ \\
\hline Congestion & Berth length (meters) & 430 & 1005 & 1200 & Linear & $\begin{array}{l}\text { (Dyck \& Ismael, } \\
\text { 2015) }\end{array}$ \\
\hline $\begin{array}{l}\text { Geographical } \\
\text { advantage }\end{array}$ & $\begin{array}{l}\text { Hinterland distance } \\
\text { (Kilometers) }\end{array}$ & 2075 & 1181 & 1000 & Concave & $\begin{array}{c}\text { (Dyck \& Ismael, } \\
\text { 2015) }\end{array}$ \\
\hline $\begin{array}{l}\text { Closeness to } \\
\text { main navigation } \\
\text { routes }\end{array}$ & $\begin{array}{l}\text { Liner shipping } \\
\text { Connectivity Index } \\
(0-100)\end{array}$ & 12.9 & 22.9 & 61.8 & Linear & $\begin{array}{c}\text { (World Bank WDI, } \\
\text { 2014) }\end{array}$ \\
\hline $\begin{array}{l}\text { Market/ cargo } \\
\text { volume }\end{array}$ & $\begin{array}{l}\text { Container throughput } \\
\text { (TEUs) }\end{array}$ & 0.22 & 1.06 & 8.81 & Linear & $\begin{array}{c}\text { (UNCTAD STAT, } \\
\text { 2014) }\end{array}$ \\
\hline $\begin{array}{l}\text { Terminal handling } \\
\text { charge }\end{array}$ & $\begin{array}{l}\text { Container handling } \\
\text { costs (US\$) }\end{array}$ & 260 & 155 & 151 & Linear & $\begin{array}{l}\text { (Dyck \& Ismael, } \\
\text { 2015) }\end{array}$ \\
\hline Port tariff & Port Tariff (US\$) & 19963 & 3442 & 3000 & Linear & $\begin{array}{c}\text { (CATRAM } \\
\text { Consultants, 2013; }\end{array}$ \\
\hline $\begin{array}{l}\text { Privileged terms } \\
\text { to ocean carriers }\end{array}$ & $\begin{array}{l}\text { \# of container lines } \\
\text { calling at terminal }\end{array}$ & 16 & 29 & 32 & Linear & $\begin{array}{c}\text { (Port Report Africa } \\
\text { 2014) }\end{array}$ \\
\hline Political stability & $\begin{array}{l}\text { Political Stability and } \\
\text { Absence of Violence/ } \\
\text { Terrorism Index } \\
(0-100)\end{array}$ & 5.34 & 41.26 & 100 & Convex & $\begin{array}{c}\text { (World Bank WGI, } \\
\text { 2014) }\end{array}$ \\
\hline Port security & \# of piracy attacks & 18 & 0 & 0 & Convex & $\begin{array}{c}\text { (ICC International } \\
\text { Maritime Bureau } \\
\text { 2015) }\end{array}$ \\
\hline Service speed & $\begin{array}{l}\text { Ship turnaround time } \\
\text { (hours }\end{array}$ & 32 & 1 & 1 & Convex & $\begin{array}{l}\text { (Knoema - Port } \\
\text { Databse, 2014) }\end{array}$ \\
\hline $\begin{array}{l}\text { Cargo handling } \\
\text { safety }\end{array}$ & $\begin{array}{l}\text { \# of quality } \\
\text { certifications }\end{array}$ & 1 & 3 & 5 & Linear & $\begin{array}{l}* * * \text { (Port of } \\
\text { Abidjan, Ivory } \\
\text { Coast, 2016) }\end{array}$ \\
\hline $\begin{array}{l}\text { Problem handling } \\
\text { in the port }\end{array}$ & $\begin{array}{l}\text { Average container } \\
\text { dwell time (days) }\end{array}$ & 42 & 7 & 5 & Convex & $\begin{array}{l}\text { (Dyck \& Ismael, } \\
\text { 2015) }\end{array}$ \\
\hline $\begin{array}{l}\text { Port } \\
\text { administration and } \\
\text { customs } \\
\text { requlation }\end{array}$ & $\begin{array}{l}\text { Corruption } \\
\text { Perception Index } \\
(0-100)\end{array}$ & 27 & 48 & 100 & Linear & $\begin{array}{c}\text { (Transparency } \\
\text { International, } 2014\end{array}$ \\
\hline
\end{tabular}

*Data used for the AFT method (Local Scale). **Data Used for VFT method (Global Scale). ***Data from different websites: (Port Autonome de Dakar [Autonomous Port of Dakar], 2016); (Bolloré Africa Logistics Nigeria, 2014); (Port Autonome de Lome [Autonomous Port of Lome], 2012); (Tema Port, 2014); (Suez Canal Container Terminal, 2016)

\subsubsection{Create Partial Value Functions}

Partial value functions were created for each attribute of the value model in order to convert the different attribute scales into one standard unit of measure, so that port alternatives of the value model could be evaluated. Since the VFT approach uses a global scale, the endpoints of the attribute scales are the minimum acceptable and ideal levels of performance for each attribute (Table 2) (Belton \& Stewart, 2002); which were valued with a 0 and 100 value scale.

Partial value functions were developed by applying the Difference Method (Watson \& Buede, 1987). The method assumes that value functions are monotonically increasing or decreasing. Five points were used to develop each partial value function, the 2 endpoints and 3 midpoints.. Most partial value functions are linear, 
which means that each unit of increase in the attribute corresponds to the same increase in the value. The partial value function related to the number of cranes attribute was developed using this rationale, as shown in Figure 4. On the other hand, other partial value functions have a concave or convex curve shape, which is the case of depth in meters, shown in Figure 4. In this example, the value increase is significantly higher once the port registers higher meters of depth resulting in a convex shape curve.
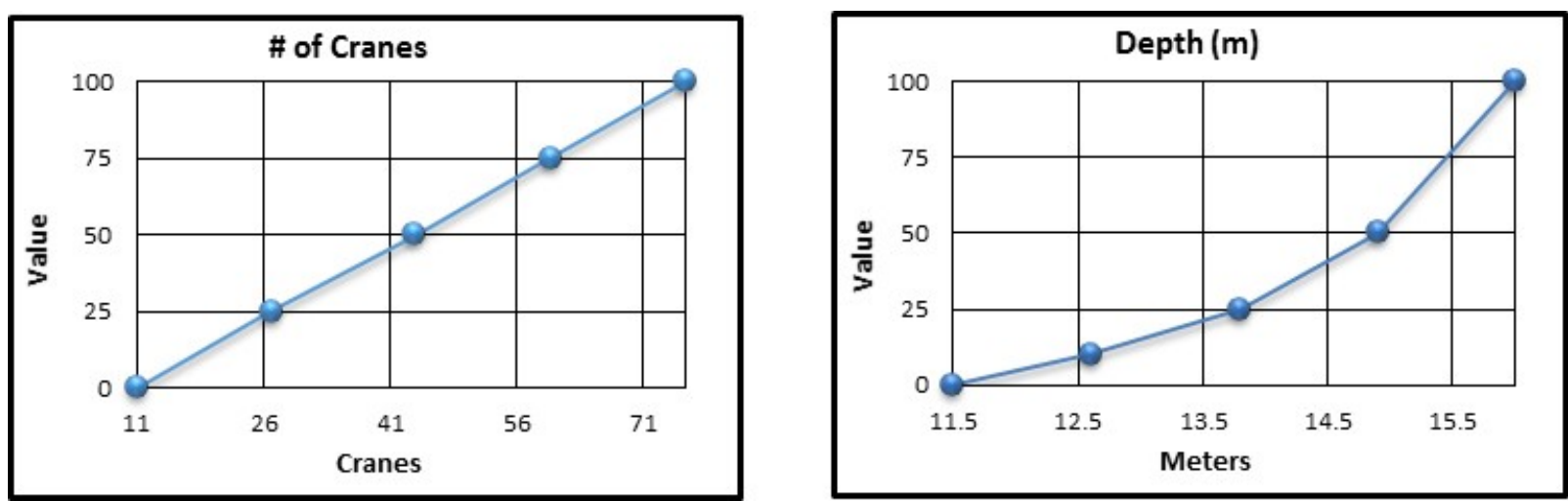

Figure 4. Examples of partial value functions with linear and convex curve shapes

\subsubsection{Assigning Weights using the Swing Weight Matrix}

Weights are critical in the MAVT because they quantify the trade-offs between attributes. Weights were assigned to the attributes of the value model using the Swing Weight Matrix method (Parnell \& Trainor, 2009). The approach considers that weights are based not only on the level of the importance of the attribute (columns in Table 3), but also on their variation of the scale (rows in Table 3) (Kirkwood, 1997).

As shown in the columns of Table 3, three levels of importance were created to classify the attributes in the matrix: External Critical Attributes, Performance and Costs Indicators, and Value Added Features. The first level of importance refers to national or regional characteristics beyond the control of the port; the second level of importance uses quantitative measures of past port performance; and the last one refers to services and characteristics that may provide future operational efficiencies.

The scale variation of the attributes are represented by the gap between the minimum acceptable and ideal scale of the attributes. Three levels (small, medium and large) were used to classify the scale variation of attributes in the matrix as shown in the rows of Table 3. Percentage change calculations were used to classify the attributes in the groups. 
Table 3. Swing weight matrix for the VFT Approach

\begin{tabular}{|c|c|c|c|c|c|c|c|c|c|c|}
\hline & \multicolumn{9}{|c|}{ Level of Importance of Attributes } \\
\hline & & $\begin{array}{c}\text { External Critical } \\
\text { Attributes }\end{array}$ & SW & NW & $\begin{array}{l}\text { Performance and Cos ts } \\
\text { Indicators }\end{array}$ & SW & NW & Value Added Features & SW & NW \\
\hline \multirow{8}{*}{ 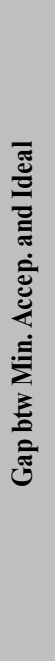 } & \multirow{2}{*}{ 总 } & Political stability & 100 & 0.12 & $\begin{array}{l}\text { Container throughput } \\
\text { (TEUs) }\end{array}$ & 65 & 0.08 & \# of cranes & 45 & 0.05 \\
\hline & & $\begin{array}{l}\text { Liner shipping } \\
\text { connectivity index }\end{array}$ & 90 & 0.11 & Ship turnaround time & 55 & 0.07 & $\begin{array}{l}\text { \# of quality } \\
\text { certifications }\end{array}$ & 30 & 0.04 \\
\hline & \multirow{3}{*}{$\begin{array}{l}\text { 音 } \\
\text { 离 }\end{array}$} & $\begin{array}{l}\text { Corruption perception } \\
\text { index }\end{array}$ & 80 & 0.09 & $\begin{array}{l}\text { Average container Dwell } \\
\text { Time }\end{array}$ & 50 & 0.06 & \multirow{3}{*}{ Berth length (m) } & \multirow{3}{*}{15} & \multirow{3}{*}{0.02} \\
\hline & & \# of piracy attacks & 75 & 0.09 & \multirow{2}{*}{ Port tariff } & \multirow{2}{*}{40} & \multirow{2}{*}{0.05} & & & \\
\hline & & $\begin{array}{l}\text { Hinterland distance } \\
(\mathrm{Km})\end{array}$ & 70 & 0.08 & & & & & & \\
\hline & \multirow{3}{*}{$\overline{\bar{\Xi}}$} & \multirow{3}{*}{ Depth (m) } & \multirow{3}{*}{50} & \multirow{3}{*}{0.06} & $\begin{array}{l}\text { Container Handling } \\
\text { Costs }\end{array}$ & 35 & 0.04 & & & \\
\hline & & & & & $\begin{array}{l}\text { \# of container lines } \\
\text { calling at terminal }\end{array}$ & 30 & 0.04 & & & \\
\hline & & & & & $\begin{array}{l}\text { Logistics Performance } \\
\text { Index }\end{array}$ & 15 & 0.02 & & & \\
\hline
\end{tabular}

SW: Swing Weights (fi) -- NW: Normalized weights (Sum of NW equals to 1 ).

* Characteristic beyond the control of the port and/or an essential characteristic to provide the service.

**Value added services or characteristics to improve service or being different from competition.

*** Port services and characteristics that may provide operational efficiencies.

Attributes with higher level of importance and large variation were placed on the top left corner of the matrix while attributes with the opposite characteristics were placed on the lower right corner of the matrix. Level of importance and variation of the scale of the attributes decrease from left to right and top to bottom respectively. The next step was to assign the swing weights $(f)$ (SW column in Table) to the attributes. For this research, it was determined that range of swing weights are between 15 (lowest) and 100 (highest), which means that swing weight of the best attribute is around 6 times more than the worst attribute. Then, swing weights were assigned to the rest of the attributes relative to the highest weighted attribute by swinging the attribute from its worst to its best level (Montibeller, 2005). Weights descended in magnitude as we moved on the diagonal from the top left to the bottom right of the swing weight matrix (Table 3). The final step is to calculate the normalized swing weights (NW column in Table 3) to sum to 1 for use in the additive value model. The formula to normalize the swing weights is shown below:

$$
w_{i}=\frac{f_{i}}{\sum_{\mathrm{i}=1}^{16} f_{i}}
$$

Where $f_{\mathrm{i}}$ is the swing weight assigned for the $i^{\text {th }}$ attribute; $i=1$ to $n$ for the number of attributes; and $w_{i}$ are the normalized swing weights.

\subsubsection{Single Dimensional Value Calculations}

Single dimensional values (Table 4) for each alternative under each attribute were calculated using the partial value functions. This data is fundamental for the overall evaluation of alternatives. 
Table 4. Single dimensional value calculations for each attribute

\begin{tabular}{|c|c|c|c|c|c|c|c|c|c|c|c|c|c|c|c|c|}
\hline Ports & \# of cranes & Depth $(m)$ & $\begin{array}{c}\text { Logistics } \\
\text { Performan } \\
\text { ce Index } \\
(1-5) \\
\end{array}$ & $\begin{array}{c}\text { Berth } \\
\text { length (m) }\end{array}$ & $\begin{array}{c}\text { Hinterland } \\
\text { distance } \\
(\mathrm{Km})\end{array}$ & $\begin{array}{c}\text { Liner } \\
\text { Shipping } \\
\text { Connectivity } \\
\text { Index } \\
(0-100) \\
\end{array}$ & $\begin{array}{c}\text { Container } \\
\text { throughput } \\
\text { (TEUs) }\end{array}$ & $\begin{array}{c}\text { Container } \\
\text { handling } \\
\text { costs (USs) }\end{array}$ & $\begin{array}{c}\text { Port tariff } \\
\text { (US\$) }\end{array}$ & $\begin{array}{c}\text { \# of } \\
\text { container } \\
\text { lines calling } \\
\text { at terminal }\end{array}$ & \begin{tabular}{|c|} 
Political \\
Stability/ \\
Terrorism \\
Index \\
$(0-100)$ \\
\end{tabular} & $\begin{array}{c}\text { \# of piracy } \\
\text { attacks }\end{array}$ & $\begin{array}{c}\begin{array}{c}\text { Ship } \\
\text { turnaround } \\
\text { time } \\
\text { (hours) }\end{array} \\
\end{array}$ & $\begin{array}{c}\text { \# of quality } \\
\text { certificatio } \\
\text { ns }\end{array}$ & $\begin{array}{c}\begin{array}{c}\text { Average } \\
\text { container } \\
\text { dwell time } \\
\text { (days) }\end{array} \\
\end{array}$ & $\begin{array}{c}\text { Corruption } \\
\text { Perception } \\
\text { Index } \\
(0-100)\end{array}$ \\
\hline Abidjan Port & 17 & 0 & 16 & 74 & 96 & 19 & 7 & 0 & 47 & 81 & 3 & 64 & 100 & 50 & 53 & 7 \\
\hline Dakar Port & 11 & 15 & 11 & 30 & 0 & 0 & 3 & 92 & 45 & 38 & 20 & 100 & 10 & 50 & 87 & 22 \\
\hline Lagos Port & 17 & 21 & 18 & 75 & 89 & 21 & 10 & 96 & 0 & 0 & 0 & 0 & 41 & 0 & 0 & 0 \\
\hline Lome Port & 0 & 5 & 0 & 0 & 95 & 13 & 0 & 37 & 94 & 31 & 19 & 76 & 100 & 0 & 47 & 3 \\
\hline Tema Port & 8 & 0 & 11 & 19 & 97 & 18 & 7 & 84 & 98 & 56 & 20 & 52 & 0 & 0 & 18 & 29 \\
\hline $\begin{array}{l}\text { Ideal Port' } \\
\text { Port Said } \\
\text { East }\end{array}$ & 100 & 100 & 100 & 100 & 100 & 100 & 100 & 100 & 100 & 100 & 100 & 100 & 100 & 100 & 100 & 100 \\
\hline
\end{tabular}

\subsubsection{Overall Evaluation of Alternatives}

Finally, the MAVT yields the overall value for the alternatives of the value model using the additive value model (Belton \& Stewart, 2002; Keeney \& Raïfa, 1976).

$$
v(x)=\sum_{i=1}^{n=16} w_{i} v_{i}\left(x_{i}\right)
$$

Where, $v(x)$ is the alternatives's value; $i=1$ to $n$ is the number of attributes; $x_{i}$ is the alternative's score on the ith attribute; $v_{i}\left(x_{i}\right)$ is the partial value function of a score of $x_{i} ; w_{i}$ is the weight of the $i^{\text {th }}$ attribute. Based on the additive value model, the overall values and ranking of the alternatives were obtained and shown in

Table 5. The Hypothetical Best alternative is a hypothetical alternative with the best score on each attribute.In addition, for a better illustration of the magnitude each attribute contributes to the overall value of each alternative, the value component graph (Figure 5) and the floating value component chart (Figure 6) were developed for the value model.

Table 5. Overall value and ranking of alternatives of the value model

\begin{tabular}{ll|l}
\hline Ports & Total Value - VFT & Ranking \\
\hline Abidjan Port & 36 & 1 \\
\hline Lome Port & 35 & 2 \\
Tema Port & 32 & 3 \\
Dakar Port & 31 & 4 \\
\hline Lagos Port & 21 & 5 \\
\hline Hypothetical Best & 54 & \\
\hline Ideal Port & 100 & \\
\hline
\end{tabular}

\subsubsection{Identifying Value Gaps}

The VFT approach offers the opportunity to improve the decision making process through the evaluation of the alternatives (Keeney, 1992). Alternatives were evaluated using the Value Component Charts (Figures 5-7) in order to identify performance of each alternative and also compare attribute value gaps for each alternative against the ideal alternative. These value gaps can help shipping lines to know the strengths and weaknesses of the port alternatives. On the other hand, container port authorities can benefit from the value gap analysis by identifying areas in which there is room for improvement for the port to improve their levels of service. The floating value component chart (Figure 6) illustrates the value gaps for each attribute of the alternatives of the value model against the ideal alternative. In addition, the white block above each attribute of the Abidjan Port alternative (Best Port) bar in Figure 7, represents the value gap compared to the ideal port. Significant value gaps exist in several attributes. For example the largest value gap between the best and ideal alternative (Figure 7) is related to the attribute: port depth in meters. On the other hand, there is not a value gap for the attribute: ship 
turnaround time in hours, because the Abidjan Port (Best Port) has the same value as the Ideal Port.

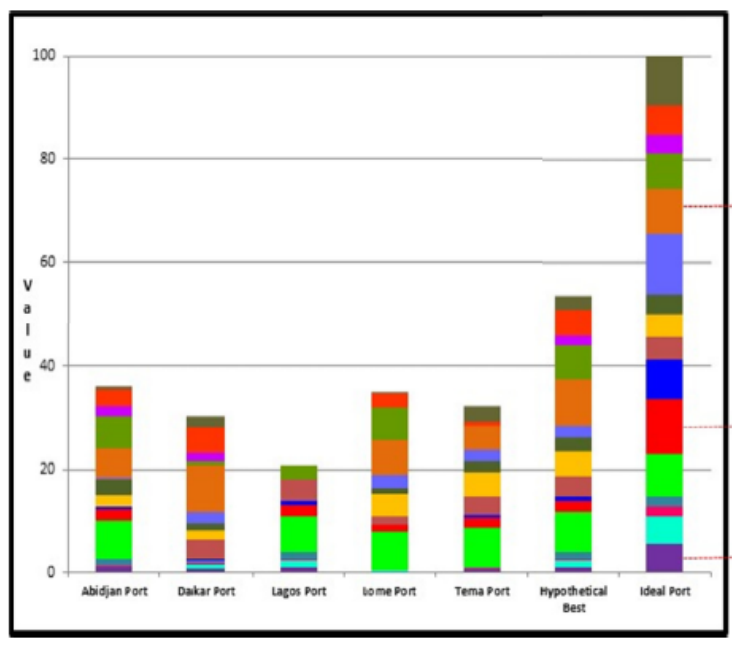

Figure 5. Value component chart

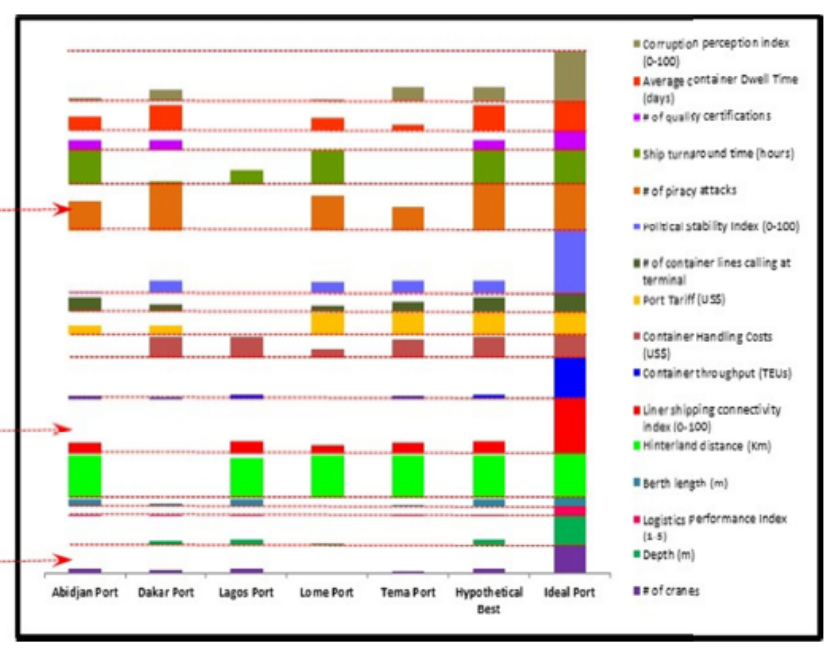

Figure 6. Floating value component chart

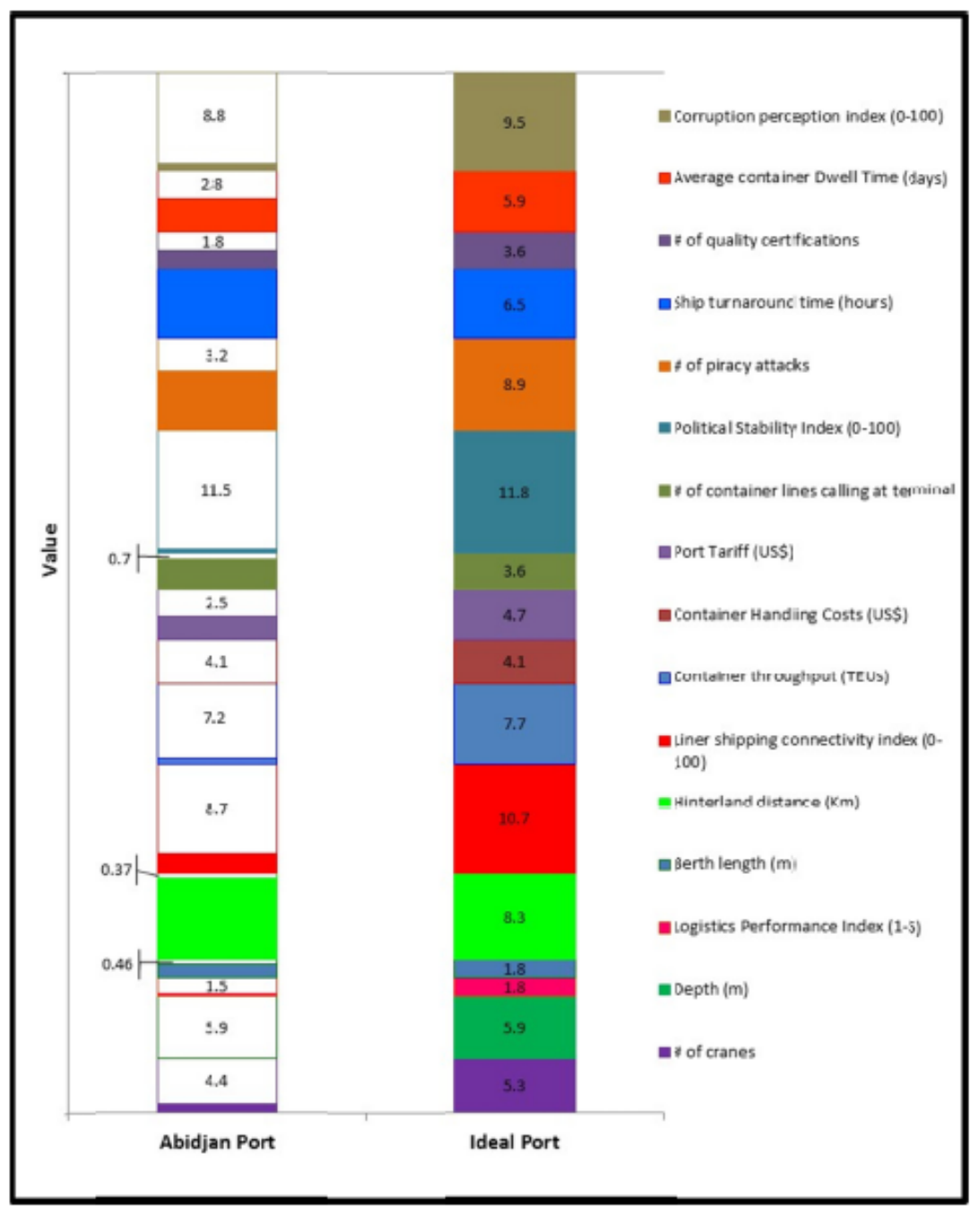

Figure 7. Value gaps between best and ideal alternatives of value model 


\subsection{Alternative Focused Thinking Approach (AFT)}

One of the goals of this research is to compare the results of the container port selection decision problem using the two approaches, VFT and AFT. The AFT approach concentrates on the alternatives of a decision problem (Keeney, 1992). To simplify the illustration of the AFT approach, only the steps and data that differs from the VFT approach will be presented.

\subsubsection{Attribute Scale and Partial Value Functions}

Since the AFT approach uses a local scale, the set of port alternatives involves only the current available ports (Abidjan, Dakar, Lagos, Lome, and Tema) for the container port selection decision problem, not including the Ideal alternative. Therefore, attribute scales will go from the minimum acceptable to the best level of performance for each attribute (Columns 3 and 4 inTable 2); which in turn, numerical standard unit of measure of 0 and 100 will be assigned respectively for the development of the partial value functions. Figure 8 illustrates two examples of partial value functions for the AFT approach, which comparing to the VFT partial value functions, the only difference will be on the highest value level of performance of each attribute.
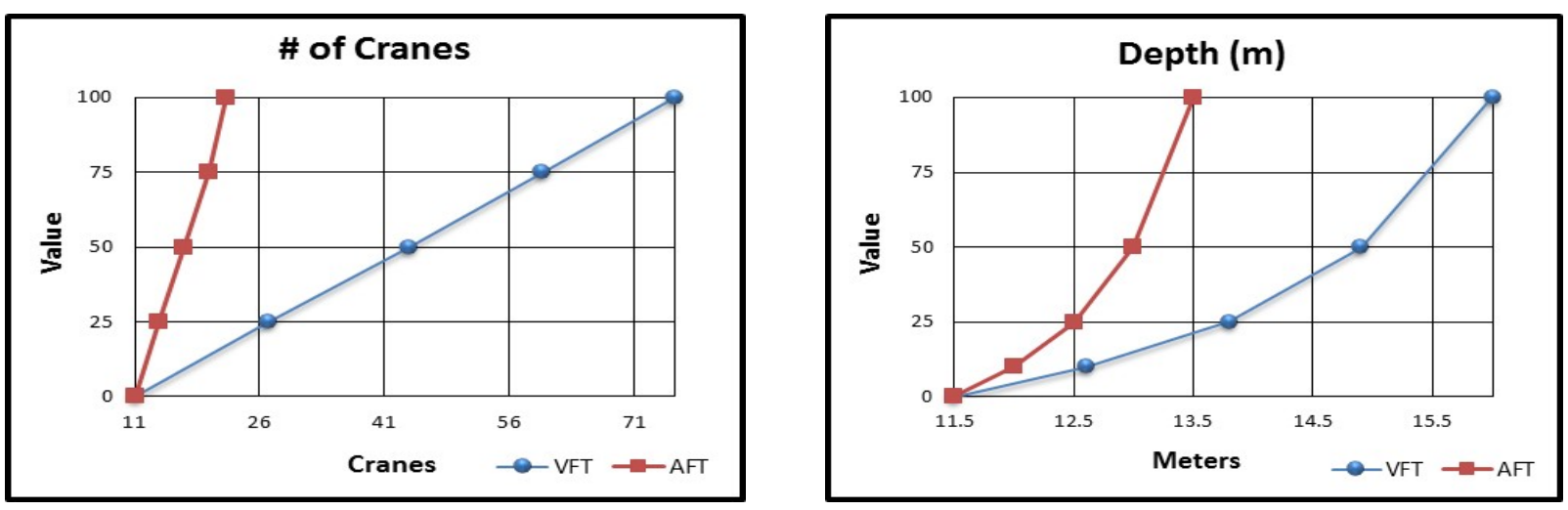

Figure 8. Examples of partial value functions for the AFT Approach and VFT Approach

\subsubsection{Assigning Weights Using the Swing Weight Matrix}

In addition, since the variation of the scale of each attribute has changed (Columns 3 and 4 in Table 2); then, the swing weight matrix for the AFT approach was reassessed following the same procedure explained in section 3.1.5. The swing weight matrix for the AFT approach is shown in Table 6. 
Table 6. Swing weight matrix for the AFT approach

\begin{tabular}{|c|c|c|c|c|c|c|c|c|c|c|}
\hline & \multicolumn{9}{|c|}{ Level of Importance of Attributes } \\
\hline & & $\begin{array}{c}\text { External Critical } \\
\text { Attributes }\end{array}$ & SW & NW & $\begin{array}{l}\text { Performance and } \\
\text { Costs Indicators }\end{array}$ & SW & NW & Value Added Features & SW & NW \\
\hline \multirow{8}{*}{ 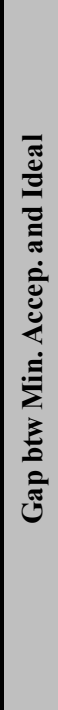 } & \multirow{2}{*}{ 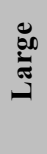 } & \# of piracy attacks & 100 & 0.12 & \multirow{2}{*}{$\begin{array}{c}\text { Container throughput } \\
\text { (TEUs) }\end{array}$} & \multirow{2}{*}{75} & \multirow{2}{*}{0.09} & \# of cranes & 60 & 0.07 \\
\hline & & Political stability & 85 & 0.10 & & & & $\begin{array}{l}\text { \# of quality } \\
\text { certifications }\end{array}$ & 50 & 0.06 \\
\hline & \multirow{4}{*}{ 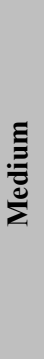 } & $\begin{array}{l}\text { Liner shipping } \\
\text { connectivity index }\end{array}$ & 80 & 0.09 & Ship turnaround time & 65 & 0.08 & \multirow{4}{*}{ Berth length (m) } & \multirow{4}{*}{30} & \multirow{4}{*}{0.03} \\
\hline & & \multirow{3}{*}{$\begin{array}{l}\text { Corruption perception } \\
\text { index }\end{array}$} & \multirow{3}{*}{70} & \multirow{3}{*}{0.08} & Port tariff & 55 & 0.06 & & & \\
\hline & & & & & $\begin{array}{l}\text { \# of container lines } \\
\text { calling at terminal }\end{array}$ & 45 & 0.05 & & & \\
\hline & & & & & $\begin{array}{l}\text { Average container } \\
\text { Dwell Time }\end{array}$ & 35 & 0.04 & & & \\
\hline & \multirow{2}{*}{$\overline{\overline{\widetilde{E}}}$} & Hinterland distance & 55 & 0.06 & $\begin{array}{l}\text { Container Handling } \\
\text { Costs }\end{array}$ & 15 & 0.02 & & & \\
\hline & & Depth (m) & 40 & 0.05 & $\begin{array}{l}\text { Logistics Performance } \\
\text { Index }\end{array}$ & 5 & 0.01 & & & \\
\hline
\end{tabular}

SW: Swing Weights $\left(f_{i}\right)$-- NW: Normalized weights (Sum of NW equals to 1).

*Characteristic beyond the control of the port and/or an essential characteristic to provide the service.

**Value added services or characteristics to improve service or being different from competition.

$* * *$ Port services and characteristics that may provide operational efficiencies.

Table 7. Single dimensional value calculations for each attribute

\begin{tabular}{|c|c|c|c|c|c|c|c|c|c|c|c|c|c|c|c|c|}
\hline Ports & \# of cranes & Depth (m) & $\begin{array}{c}\text { Logistics } \\
\text { Performance } \\
\text { Index (1-5) }\end{array}$ & $\begin{array}{c}\text { Berth } \\
\text { length }(m)\end{array}$ & $\begin{array}{c}\text { Hinterland } \\
\text { distance } \\
(\mathrm{Km})\end{array}$ & $\begin{array}{r}\text { Liner Shipping } \\
\text { Connectivity } \\
\text { Index (0-100) }\end{array}$ & $\begin{array}{c}\text { Container } \\
\text { throughput } \\
\text { (TEUs) }\end{array}$ & $\begin{array}{c}\text { Container } \\
\text { handling } \\
\text { costs (US\$) }\end{array}$ & $\begin{array}{c}\text { Port tariff } \\
\text { (US\$) }\end{array}$ & $\begin{array}{c}\text { \# of } \\
\text { container } \\
\text { lines calling } \\
\text { at terminal }\end{array}$ & \begin{tabular}{|c|} 
Political \\
Stability/ \\
Terrorism \\
Index \\
$(0-100)$ \\
\end{tabular} & $\begin{array}{c}\text { \# of piracy } \\
\text { attacks }\end{array}$ & $\begin{array}{c}\text { Ship } \\
\text { turnaround } \\
\text { time (hours) }\end{array}$ & $\begin{array}{c}\text { \# of quality } \\
\text { certifications }\end{array}$ & $\begin{array}{c}\text { Average } \\
\text { container } \\
\text { dwell time } \\
\text { (days) }\end{array}$ & $\begin{array}{c}\text { Corruption } \\
\text { Perception } \\
\text { Index } \\
(0-100) \\
\end{array}$ \\
\hline Abidjan Port & 100 & 0 & 90 & 99 & 99 & 90 & 67 & 0 & 48 & 100 & 8 & 64 & 100 & 100 & 63 & 25 \\
\hline Dakar Port & 58 & 50 & 60 & 40 & 0 & 0 & 27 & 95 & 46 & 50 & 100 & 100 & 10 & 100 & 100 & 75 \\
\hline Lagos Port & 100 & 100 & 100 & 100 & 96 & 100 & 100 & 100 & 0 & 0 & 0 & 0 & 41 & 0 & 0 & 0 \\
\hline Lome Port & 0 & 10 & 0 & 0 & 98 & 62 & 0 & 38 & 97 & 42 & 92 & 76 & 100 & 0 & 55 & 10 \\
\hline Tema Port & 42 & 0 & 63 & 25 & 100 & 88 & 73 & 88 & 100 & 75 & 98 & 52 & 0 & 0 & 20 & 100 \\
\hline $\begin{array}{l}\text { Hypothetical } \\
\text { Best }\end{array}$ & 100 & 100 & 100 & 100 & 100 & 100 & 100 & 100 & 100 & 100 & 100 & 100 & 100 & 100 & 100 & 100 \\
\hline
\end{tabular}

Table 8. Overall value and ranking of alternatives for the AFT Approach

\begin{tabular}{ll|l}
\hline Ports & Total Value - AFT & Ranking \\
\hline Abidjan Port & 66 & 1 \\
\hline Tema Port & 61 & 2 \\
Dakar Port & 56 & 3 \\
Lome Port & 50 & 4 \\
\hline Lagos Port & 44 & 5 \\
\hline Hypothetical Best & 100 & \\
\hline
\end{tabular}




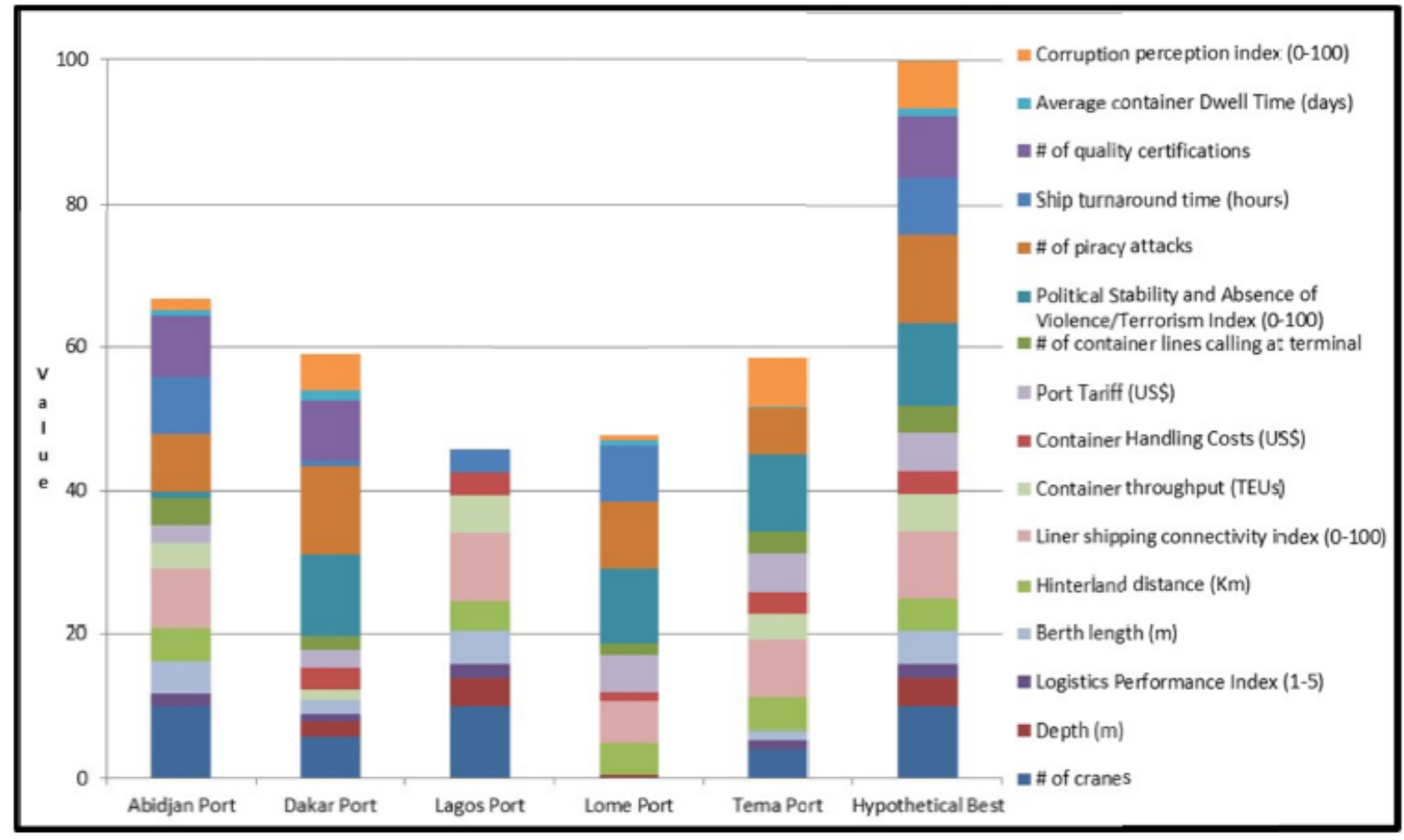

Figure 9. Value component chart for the AFT Approach

\subsubsection{Single Dimensional Value Calculations and Overall Evaluation of Alternatives}

Using the new AFT partial value functions and the alternative scores presented above (Table 1), single dimensional value calculations for each alternative under each attribute was developed and shown in Table 7 . Finally, using the additive value model (See section 3.1.7), the overall value of each alternative was calculated for the AFT approach. The Hypothetical Best alternative was included among the alternatives of the model, so that decision makers can develop comparisons and insights.

The overall values and ranking of the port alternatives are presented in Table 8. In addition, the overall value for each alternative of the AFT approach is presented on the value component chart of Figure 9. The value component chart provides the contribution of each attribute to the overall value of the alternative compared to the hypothetical best alternative.

\subsection{Comparing VFT vs AFT Results}

Based on the VFT and AFT results shown in Table 9, Abidjan Port is the highest value alternative in West Africa for the shipping lines. Both approaches provide the same highest and lowest value alternatives. However, the $2^{\text {nd }}$, $3^{\text {rd }}$, and $4^{\text {th }}$ ranked alternatives are not the same. 
Table 9. Comparison of alternative overall values between VFT and AFT

\begin{tabular}{l|c|c|c|c}
\hline \multirow{2}{*}{ Alternatives } & \multicolumn{2}{|c|}{ VFT } & \multicolumn{2}{c}{ AFT } \\
\cline { 2 - 5 } & Value & Ranking & Value & Ranking \\
\hline Abidjan Port & 36 & $\mathbf{1}$ & 66 & $\mathbf{1}$ \\
\hline Lome Port & 35 & $\mathbf{2}$ & 50 & $\mathbf{4}$ \\
\hline Tema Port & 32 & $\mathbf{3}$ & 61 & $\mathbf{2}$ \\
\hline Dakar Port & 31 & $\mathbf{4}$ & 56 & $\mathbf{3}$ \\
\hline Lagos Port & 21 & $\mathbf{5}$ & 44 & $\mathbf{5}$ \\
\hline
\end{tabular}

\section{Discussion}

The applicability of the MAVT with VFT approach for a port selection decision problem has been demonstrated in this research and also compared with the traditional AFT approach. In order to score port alternatives, available quantitative port data was used, rather than using data from surveys and questionnaires. Decision makers can obtain more insights using MAVT with VFT rather than with AFT, because it concentrates on the understanding of the values of the decision makers and allows comparison of the current alternatives with the ideal situation, rather than just focusing on the current alternatives.

Analyzing the overall value gaps for the VFT approach, Abidjan Port has the opportunity to improve in the following attributes: depth, container handling costs, political stability, and corruption perception, in order to be closer to the ideal port of the region. Abidjan Port shows dominance over other alternatives for most of the other attributes of the value model. The value gaps charts (Figure 5, Figure 6 and Figure 7) were used to understand better how the overall value for each port alternative is constructed and what attributes can be defined as strengths and weaknesses for each port alternative of the VFT value model.

By using the swing weight method, it offers the advantage of assigning weight to attributes considering their level of importance and the gap between the minimum acceptable and ideal range scale, rather than using only a subjective approach. Figure 10 illustrates the variations of the weights between the two approaches.

Another observation is that attribute weights influence the final rankings on both methods. Sensitivity analysis was performed for every single attribute on weights and container handling cost is the only attribute that would result on a change of decision.

To obtain a cost versus value chart, the VFT value of the cost attributes were plotted against the value of the rest of the attributes in order to identify the cost effect on the dominant alternatives (Figure 11) (Parnell, Bresnick, Tani, \& Johnson, 2013). Triangles were used to identify the two dominant alternatives, Abidjan Port which has the highest value but is the most expensive alternative and Lome Port which has the second best value and low cost among all alternatives. We believe this provides a useful perspective for decision makers that would be better with if the total costs were plotted against the value (See future research). 


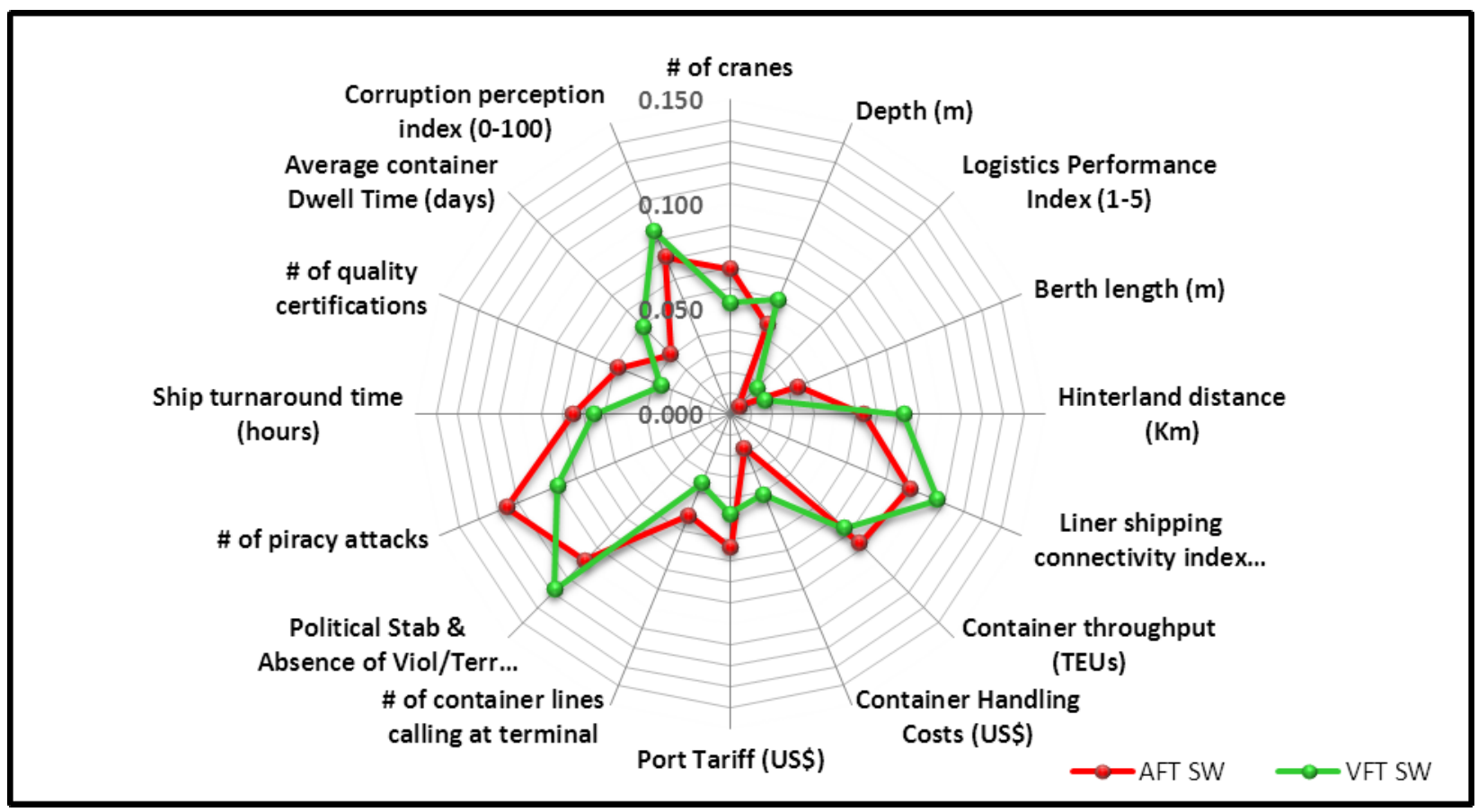

Figure 10. Weight comparison of AFT vs VFT Approaches

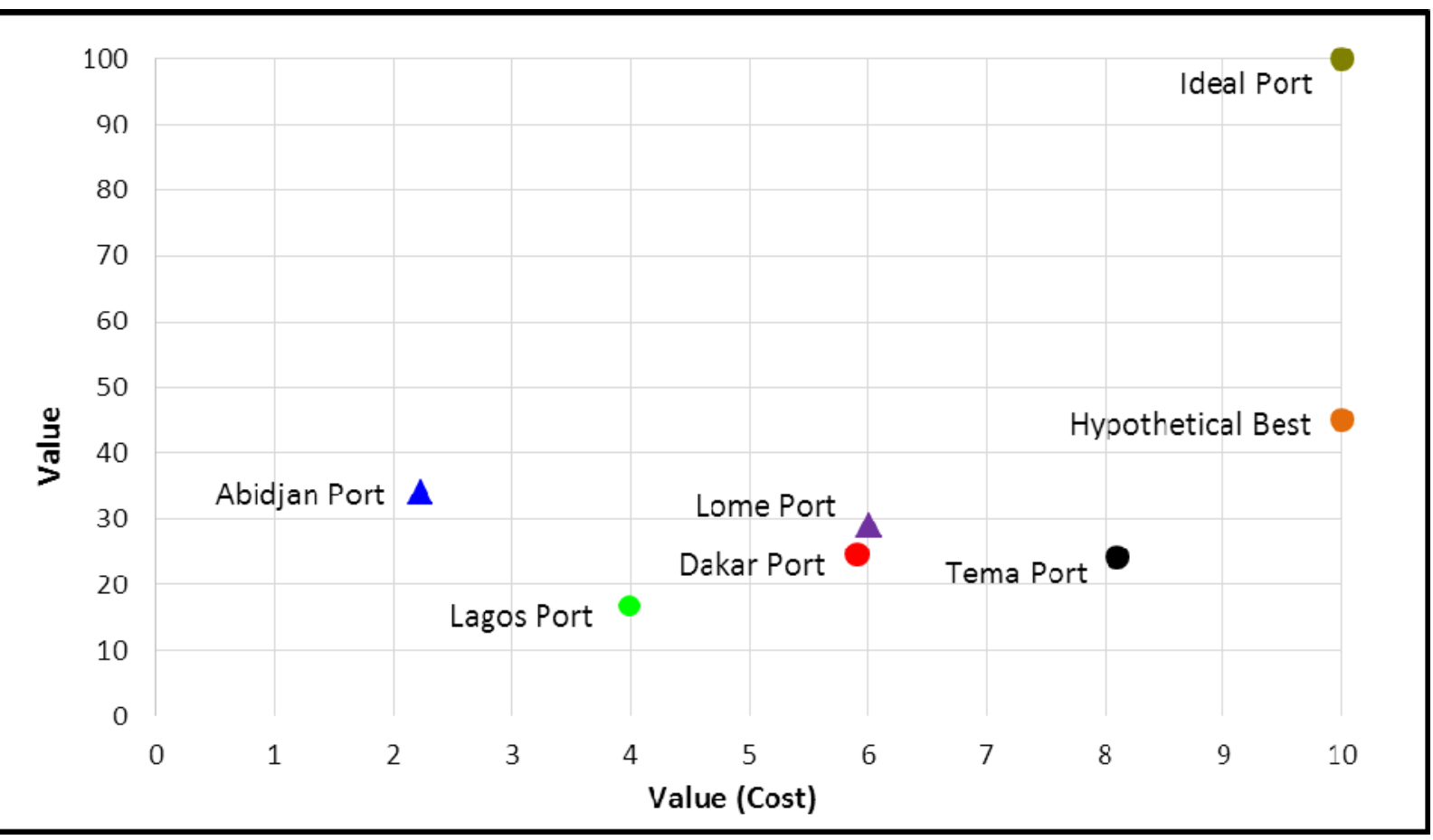

Figure 11. Cost value vs value for the VFT Approach

\section{Future Research}

Future work includes the port selection decision problem using MAVT with VFT, but in a different region such as a set of ports serving the Transpacific route (Asia to North America) through the Panama Canal. Since the expansion of the Panama Canal was completed recently, it is expected to increase the container traffic through this route using US ports. In addition, we plan to develop a lifecycle costs model separately and include both value and cost uncertainty. 


\section{Acknowledgments}

This research was supported by a scholarship from the National Bureau of Science, Technology and Innovation (SENACYT) of Panama.

\section{References}

Alanda, A., \& Yang, Z. (2013). Hub-Port Choice in West Africa. In International Forum on Shipping, Ports and Airports (IFSPA) (pp. 405-413).

Belton, V., \& Stewart, T. (2002). Multiple criteria decision analysis: an integrated approach. Boston: Kluwer. https://doi.org/10.1007/978-1-4615-1495-4

Bolloré Africa Logistics Nigeria. (2014). Retrieved from http://www.bollore-africa-logistics-kenya.com/about-us/bollore-africa-logistics-in-kenya/iso-90012008-cert ification.html (accessed January 2016).

CATRAM Consultants. (2013). Market study on container terminals in West and Central Africa.

Chang, Y. T., Lee, S. Y., \& Tongzon, J. L. (2008). Port selection factors by shipping lines: Different perspectives between trunk liners and feeder service providers. Marine Policy, 32(6), 877-885. https://doi.org/10.1016/j.marpol.2008.01.003

Chou, C. (2007). A fuzzy MCDM method for solving marine transshipment container port selection problems. Applied Mathematics and Computation, 186(1), 435-444. https://doi.org/10.1016/j.amc.2006.07.125

Chou, C. (2010). AHP model for the container port choice in the multiple-ports region. Journal of Marine Science and Technology, 18(2), 221-232.

Davis, C., Deckro, R., \& Jackson, J. (2000). A value focused model for a C4 network. Journal of Multicriteria $\begin{array}{llll}\text { Decision } & \text { Analysis, } & 9(4), & 138 .\end{array}$ https://doi.org/10.1002/1099-1360(200007)9:4\%3C138::AID-MCDA273\%3E3.0.CO;2-S

De Icaza, R. (2017). Decision Support System for Containor Port Selection using Multiple-Objective Decision Analysis. Dissertation, Univeristy of Arkansas, Fayetteville, AR.

De Icaza, R., Parnell, G., \& Aloysius, J. (2015). Port Selection Analysis: Trends and Gaps.

De Langen, P. (2007). Port competition and selection in contestable hinterlands; the case of Austria. European Journal of Transport and Infrastructure Research, 7(1), 1-14.

Dyck, G., \& Ismael, H. (2015). Multi-Criteria Evaluation of Port Competitiveness in West Africa Using Analytic Hierarchy Process (AHP). American Journal of Industrial and Business Management, 5(06), 432-446. https://doi.org/10.4236/ajibm.2015.56043

Frankel, E. (1992). Hierarchical logic in shipping policy and decision-making. Maritime Policy \& Management, 19(3), 211-221. https://doi.org/10.1080/751248662

Garcia-Alonso, L., \& Sanchez-Soriano, J. (2009). Port selection from a hinterland perspective. Maritime Economics \& Logistics, 11(3), 260-269. https://doi.org/10.1057/mel.2009.9

Gohomene, D., Bonsal, S., Maistralis, E., Wang, J., \& Li, K. (2015). The Attractiveness of Ports in West Africa: Some Lessons from Shipping Lines' Port Selection. Growth and Change., 47(3), 416-426. https://doi.org/10.1111/grow.12133

Grosso, M., \& Monteiro, F. (2009). Relevant strategic criteria when choosing a container port-the case of the port of Genoa. Research in Transport and Logistics, 299.

Guy, E., \& Urli, B. (2006). Port selection and multicriteria analysis: an application to the Montreal-New York alternative. Maritime Economics \& Logistics, 8(2), 169-186. https://doi.org/10.1057/palgrave.mel.9100152

ICC International Maritime Bureau. (2015). Piracy and Armed Robbery Againts Ships. London. Retrieved from http://www.hellenicshippingnews.com/wp-content/uploads/2015/01/2014-Annual-IMB-Piracy-Report-ABR IDGED.pdf (accessed January 2016).

IMO. (2012). International Maritime Organization. International Shipping Facts and Figures - Information Resources on Trade, Safety, Security, Environment. Maritime Knowledge Centre. London. Retrieved from http://www.imo.org/en/KnowledgeCentre/ShipsAndShippingFactsAndFigures/TheRoleandImportanceofInt ernationalShipping/Documents/International\%20Shipping\%20-\%20Facts\%20and\%20Figures.pdf (accessed March 2016). 
Keeney, R. L. (1992). Value-focused thinking: A path to creative decisionmaking. Harvard University Press.

Keeney, R. L. (1994). Creativity in decision making with value-focused thinking. Sloan Management Review, $35(4), 33$.

Keeney, R. L., \& Raïffa, H. (1976). Decisions with multiple objectives: preferences and value tradeoffs. New York: Wiley.

Kim, J. Y. (2014). Port user typology and representations of port choice behavior: A Q-methodological study. Maritime Economics \& Logistics, 16(2), 165-187. https://doi.org/10.1057/mel.2013.26

Kirkwood, C. (1997). Strategic Decision Making Multiobjective Decision Analysis with Spreadsheets. Belmont, California: Wadsworth Publishing Company.

Knoema - Port Databse. (2014). Retrieved from https://knoema.com/PRTDT2016 (accessed February 2016).

Lirn, T., Thanopoulou, H., Beynon, M., \& Beresford, A. (2004). An application of AHP on transhipment port selection: a global perspective. Maritime Economics \& Logistics, 6(1), 70-91. https://doi.org/10.1057/palgrave.mel.9100093

Magala, M., \& Sammons, A. (2008). A new approach to port choice modelling. Maritime Economics \& Logistics, 10(1), 9-34. https://doi.org/10.1057/palgrave.mel.9100189

Malchow, M., \& Kanafani, A. (2001). A disaggregate analysis of factors influencing port selection. Maritime Policy \& Management, 28(3), 265-277. https://doi.org/10.1080/03088830110060840

Malchow, M., \& Kanafani, A. (2004). A disaggregate analysis of port selection. Transportation Research Part E: Logistics and Transportation Review, 40(4), 317-337. https://doi.org/10.1016/j.tre.2003.05.001

Mangan, J., Lalwani, C., \& Gardner, B. (2002). Modelling port/ferry choice in RoRo freight transportation. $\begin{array}{lllll}\text { International Journal of Transport } & \text { Management, } & 1(1), & \text { 15-28. }\end{array}$ https://doi.org/10.1016/S1471-4051(01)00003-9

Montibeller, G. (2005). From (and to) a new generation of multi-criteria decision analysts: an introduction to the field and a personal view on its future. In Keynote Papers-YOR14 Conference. The Operational Research Society Press: Birmingham (ISBN 090344033 4).

Murphy, P. R. (1992). Port selection criteria: an application of a transportation research framework. Logistics and Transportation Review, 28(3), 237.

Murphy, P., \& Daley, J. (1994). A comparative analysis of port selection factors. Transportation Journal, 15-21.

Murphy, P., Dalenberg, D., \& Daley, J. (1988). A contemporary perspective of international port operations. Transportation journal, 23-32.

Murphy, P., Daley, J., \& Dalenberg, D. (1991). Selecting links and nodes in international transportation: an intermediary's perspective. Transportation journal, 33-40.

$\mathrm{Ng}, \mathrm{K}$. (2006). Assessing the attractiveness of ports in the North European container transhipment market: an agenda for future research in port competition. Maritime Economics and Logistics, 8(3), 234-250. https://doi.org/10.1057/palgrave.mel.9100158

Nir, A., Lin, K., \& Liang, G. (2003). Port choice behaviour--from the perspective of the shipper. Maritime Policy \& Management, 30(2), 165-173. https://doi.org/10.1080/0308883032000069262

Panayides, P., \& Song, D. (2012). Determinants of Users' Port Choice. The Blackwell Companion to Maritime Economics, 599-622.

Parnell, G., \& Trainor, T. E. (2009). Using the Swing Weight Matrix to Weight Multiple Objectives. INCOSE International Symposium, 19(1), 283-298. https://doi.org/10.1002/j.2334-5837.2009.tb00949.x

Parnell, G., Bresnick, T., Tani, S., \& Johnson, E. (2013). Handbook of decision analysis (Vol. 6). New Jersey: John Wiley \& Sons. https://doi.org/10.1002/9781118515853

Parnell, G., Hughes, D., Burk, R., Driscoll, P., Kucik, P., MoraleS, B., \& Nunn, L. (2013). Invited Review - Survey of Value - Focused Thinking: Applications, Research Developments and Areas for Future Research. Journal of Multi - Criteria Decision Analysis, 20(1-2), 49-60. https://doi.org/10.1002/mcda.1483

Port Autonome de Dakar [Autonomous Port of Dakar]. (2016). Retrieved from http://www.portdakar.sn/index.php (accessed January 2016). 
Port Autonome de Lome [Autonomous Port of Lome]. (2012). Retrieved from http://www.togo-port.net/index.php?option=com_content\&view=article\&id=204:le-port-de-lome-certifie-is o-9001-version-2008\&catid=43:actualites\&Itemid=104 (accessed February 2016).

Port of Abidjan, Ivory Coast. $\quad$ (2016). $\quad$ Retrieved from http://www.bollore-africa-logistics.com/en/ports-and-terminals/ (accessed February 2016).

Port Report Africa. (2014). Retrieved from http://www.portoverview.com (accessed May 2016).

Saaty, T. (1980). The analytic hierarchy process: planning, priority setting, resources allocation. New York: McGraw.

Sanchez, R., Ng, A., \& Garcia-Alonso, L. (2011). Port Selection Factors and Attractiveness: The Service Providers' Perspective. Transportation $\quad$ Journal, $141-161$. https://doi.org/10.5325/transportationj.50.2.0141

Slack, B. (1985). Containerization, inter-port competition, and port selection. Maritime Policy and Management, 12(4), 293-303. https://doi.org/10.1080/03088838500000043

Song, D., \& Yeo, K. (2004). A competitive analysis of Chinese container ports using the analytic hierarchy process. Maritime Economics \& Logistics, 6(1), 34-52. https://doi.org/10.1057/palgrave.mel.9100096

Steven, A., \& Corsi, T. (2012). Choosing a port: An analysis of containerized imports into the US. Transportation Research Part E: Logistics and Transportation Review, 48(4), 881-895. https://doi.org/10.1016/j.tre.2012.02.003

Suez Canal Container Terminal. (2016). Retrieved from http://www.scctportsaid.com/organization_hsse.php (accessed February 2016).

Tang, L., Low, J., \& Lam, S. (2011). Understanding port choice behavior-a network perspective. Networks and Spatial Economics, 11(1), 65-82. https://doi.org/10.1007/s11067-008-9081-8

Tema Port. (2014). Retrieved from http://www.ghanaports.gov.gh/page/19/Port-Highlights (accessed February 2016).

Tiwari, P., Itoh, H., \& Doi, M. (2003). Shippers' port and carrier selection behaviour in China: a discrete choice analysis. Maritime Economics \& Logistics, 5(1), 23-39. https://doi.org/10.1057/palgrave.mel.9100062

Tongzon, J. (2002). Port choice determinants in a competitive environment. In Proceedings of Annual Conference and Meeting of the International Association of Maritime Economists. Panama: IAME.

Tongzon, J. L. (2009). Port Choice and freight forwarders. Transportation Research Part E: Logistics and Transportation Review, 45(1), 186-195. https://doi.org/10.1016/j.tre.2008.02.004

Tongzon, J. L., \& Sawant, L. (2007). Port choice in a competitive environment: from the shipping lines' perspective. Applied Economics, 39(4), 477-492.

Transparency International. (2014). Retrieved from Corruption Perception Index 2014: Results: https://www.transparency.org/cpi2014/results (accessed February 2016).

Ugboma, C., Ugboma, O., \& Ogwude, I. (2006). An analytic hierarchy process (AHP) approach to port selection decisions-empirical evidence from Nigerian ports. Maritime Economics \& Logistics, 8(3), 251-266. https://doi.org/10.1057/palgrave.mel.9100160

UNCTAD STAT. (2014). Retrieved from unctadstat.unctad.org/wds/ (accessed January 2016).

Veldman, S., \& Bückmann, E. (2003). A model on container port competition: an application for the west European container hub-ports. Maritime Economics \& Logistics, 5(1), 3-22. https://doi.org/10.1057/palgrave.mel.9100058

Veldman, S., Garcia-Alonso, L., \& Vallejo-Pinto, J. (2011). Determinants of container port choice in Spain. Maritime Policy \& Management, 38(5), 509-522. https://doi.org/10.1080/03088839.2011.597450

Watson, S., \& Buede, D. (1987). Decision synthesis: the principles and practice of decision analysis. New York: Cambridge University Press.

Wiegmans, B., Hoest, A., \& Notteboom, T. (2008). Port and terminal selection by deep-sea container operators. Maritime Policy \& Management, 35(6), 517-534. https://doi.org/10.1080/03088830802469329

World Bank LPI. (2014). Retrieved from http://lpi.worldbank.org/international/global (accessed January 2016).

World Bank WDI. (2014). Retrieved from http://wdi.worldbank.org/tables (accessed January 2016). 
World Bank WGI. (2014). Retrieved from http://info.worldbank.org/governance/wgi (accessed January 2016).

World Shipping Council. (2016). Retrieved from http://www.worldshipping.org/about-the-industry/global-trade/top-50-world-container-ports ～(accessed March 2016).

Wright, G., \& Goodwin, P. (1999). Future-focussed thinking: combining scenario planning with decision analysis. Journal of Multicriteria Decision Analysis, $8(6), \quad 311$. https://doi.org/10.1002/1099-1360(199911)8:6\%3C311::AID-MCDA256\%3E3.0.CO;2-T

$\mathrm{Wu}$, Y., Liu, J., \& Peng, C. (2014). Analysis of port and inland transport mode selection. In Service Systems and Service Management (ICSSSM) 2014 11th International Conference (pp. 1-6). IEEE.

Yeo, G., Ng, A., Lee, P., \& Yang, Z. (2014). Modelling port choice in an uncertain environment. Maritime Policy \& Management, 41(3), 251-267. https://doi.org/10.1080/03088839.2013.839515

\section{Copyrights}

Copyright for this article is retained by the author(s), with first publication rights granted to the journal.

This is an open-access article distributed under the terms and conditions of the Creative Commons Attribution license (http://creativecommons.org/licenses/by/4.0/). 